\title{
Alfred Werner's Chemistry of Dinuclear Complexes - A Test Case of Werner's Intuition
}

\author{
Olivier Blacque and Heinz Berke*
}

\begin{abstract}
The re-investigation of four original tris-bridged dinuclear dicobalt complexes from the Werner collection of the University of Zurich by X-ray diffraction studies is described. The complex $\left[\mathrm{Co}_{2}\left(\mathrm{NH}_{3}\right)_{6}\left(\mu-\mathrm{NH}_{2}\right)\right.$ $\left.(\mu-\mathrm{OH})\left(\mu-\mathrm{O}_{2}\right)\right]\left(\mathrm{NO}_{3}\right)_{3}$ was studied recently. As the most interesting feature it was found to contain a $\mu$-superoxo bridge, recognized by Alfred Werner and his coworker as an asymmetric peroxo bridge. The newly established $\mu$-mono- and diacetato structures from crystals of the Werner collection, $\left[\mathrm{Co}_{2}\left(\mathrm{NH}_{3}\right)_{6}(\mu-\mathrm{OH})_{2}\left(\mu-\mathrm{O}_{2} \mathrm{CMe}\right)\right]\left(\mathrm{NO}_{3}\right)_{3} \cdot \mathrm{H}_{2} \mathrm{O}$ and $\left[\mathrm{Co}_{2}\left(\mathrm{NH}_{3}\right)_{6}(\mu-\mathrm{OH})\left(\mu-\mathrm{O}_{2} \mathrm{CMe}\right)_{2}\right]\left(\mathrm{NO}_{3}\right)_{3} \cdot \mathrm{H}_{2} \mathrm{O}$, were assigned by Alfred Werner and his co-workers as mono- or di-bridged systems with the water functioning as $\eta^{1}$-aqua ligands and not, as revealed by the $\mathrm{X}$-ray diffraction studies, as solvate molecules. Similarly the exact nature of the $\mu(\mathrm{N}, \mathrm{O})$ nitrito bridge in the structure of the $\left[\mathrm{CO}_{2}\left(\mathrm{NH}_{3}\right)_{6}(\mu-\mathrm{OH})_{2}\left(\mu-\mathrm{O}_{2} \mathrm{~N}\right)\right]\left(\mathrm{NO}_{3}\right)_{3} \cdot \mathrm{H}_{2} \mathrm{O}$ complex from the Werner collection was left open in Werner's and his coworker's description. Only the accuracy of the X-ray diffraction study could ascertain any earlier 'good guess'. The assignment of the bridges of bridged dinuclear structures at Werner's time are well conceived considering the lack of appropriate analytical tools. The structural assignments of Alfred Werner for the discussed dinuclear complexes are therefore considered to deviate only marginally from the real structures. They are testimonies of Alfred Werner's predictive abilities in coordination chemistry supported by his prepared mind, his great abilities of intuition and conceptual thinking.
\end{abstract}

Keywords: Ammine ligands · Bridging ligands · Cobalt · Dinuclear complexes · Werner, Alfred · Werner collection of original samples, University of Zurich

\section{Intuition and Conceptual Thinking as the Main Sources of Chemical Creativity}

Intuition is defined as the ability to acquire knowledge without inference and/or the use of reason. In this context, Albert Einstein, the contemporary of Alfred Werner, once said: "intuition is more important than knowledge" stressing the prominent importance of this ability. But intuition is based on knowledge and without knowledge there is no intuition. Knowledge is reason-based, but in the interplay with intuition it directs intuition into channels away from mere fantasy to the creation of reality. Intuition has the facets of imagination and inspiration and much what contemporaries of Alfred Werner (presumably not Albert Einstein, since Einstein and Werner might have never met) reported about him, was that he was a man of great imagination and inspiration.

\footnotetext{
${ }^{\star}$ Correspondence: Prof. Dr. H. Berke Chemisches Institut, Universität Zürich Winterthurerstrasse 190, CH-8057 Zurich E-mail: hberke@chem.uzh.ch
}

Another aspect of the ingenious Alfred Werner and his chemical personality is his outstanding capability to think conceptually as can be derived from many sources, among others his Nobel lecture 'Über die Konstitution und Konfiguration von Verbindungen höherer Ordnung' ${ }^{[1]}$ (Fig. 1).
In the first sentences of his Nobel lecture he tells us about the basis of his thinking, from which he drew valuable conclusions on the world of coordination compounds.

Although Alfred Werner's 'theory' was not built on solid physical grounds, it served well as a heuristic representative

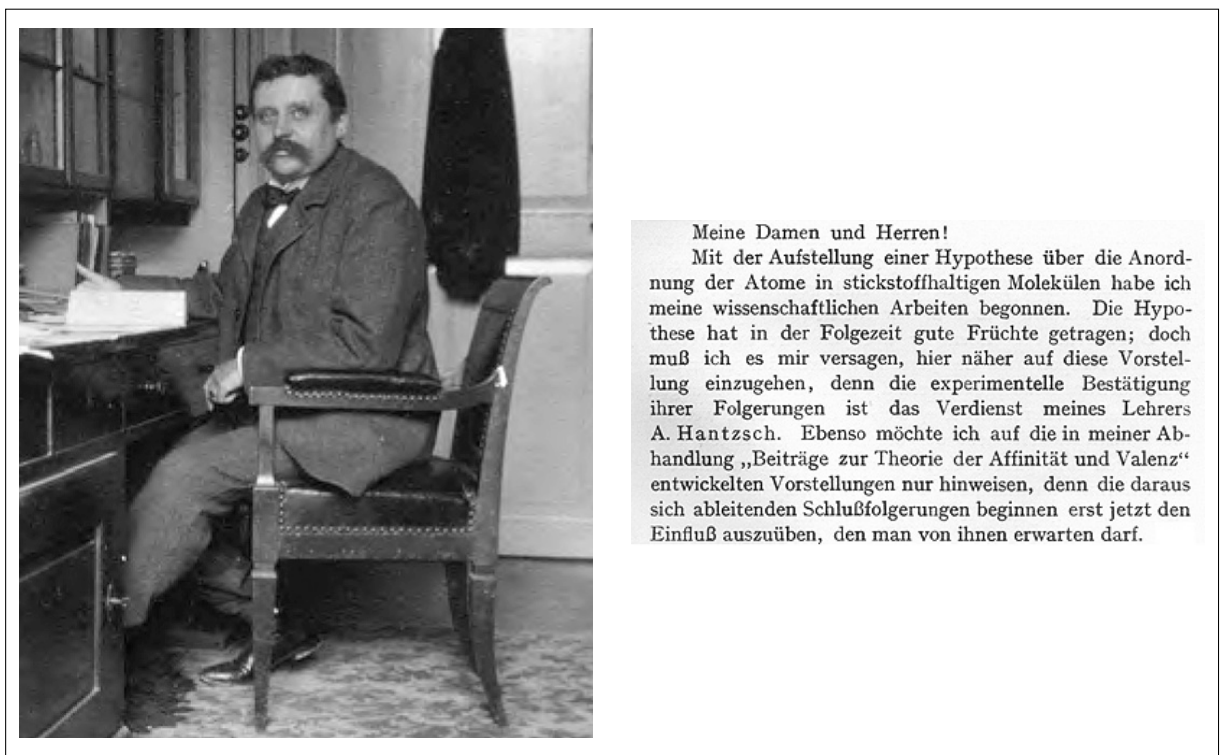

Fig.1. Left: Photograph of Alfred Werner sitting in his office (picture: University of Zurich). Right: Excerpt from Alfred Werner's Nobel lecture 'Über die Konstitution und Konfiguration von Verbindungen höherer Ordnung' presented after reception of his Nobel prize in Stockholm on December 11, 1913. ${ }^{[1]}$ 
method to successfully match reality with conclusions by analogy. Paul Pfeiffer, his student and later on his colleague, criticized Alfred Werner's 'theory' as having a too undefined perception of the word 'Valenz', as described in the foreword of the 5th edition of Werner's book. ${ }^{[2 e]} \mathrm{A}$ detailed description of his 'theory' is given in a recent article. ${ }^{[3]}$ The criticism of Paul Pfeiffer may be correct, but in its essence Alfred Werner's coordination 'theory' of 1892 - actually, in these early days his conceptual thinking was much ahead of his time - had consistency by itself and coped well with the factual level so that it could become an inductive formula as a platform for the creation of ideas and explanations. All this was mixed with the outstanding ability of intuition and indeed, this article is to witness Alfred Werner's great intuitive abilities not requiring an exact theory.

\section{Tracing the Way Alfred Werner Entered into the Chemistry of Polynuclear Complexes}

In his book 'Neuere Anschauungen auf dem Gebiete der anorganischen Chemie' Alfred Werner ${ }^{[2]}$ rationalizes that, based on his coordination and binding theory in complexes, secondary valencies ${ }^{[3]}$ are responsible for the linking of 'metal atoms' via bridging ligands, in contrast to the $\mathrm{C}-\mathrm{C}$ linking of organic compounds, which make use of primary valencies. ${ }^{[3]}$ Fig. 2 is directly taken from his book, which illustrates this idea.

Although Alfred Werner's theory was not built on solid physical grounds, it served well as a representative heuristic method to successfully match reality to conclusions by analogy. Werner's book was for a very long period of time also of great practical value. This aspect may have contributed to its distinction with the 'Chemical Breakthrough Award' from the American Chemical Society, Division of History, in 2007.[2f]

In his typical way, Alfred Werner thus illustrated the bridge-building process by applying the notion of primary and secondary valencies. ${ }^{[3]}$ A related view would be the deprotonation of an ammine ligand and replacement of a ligand of another complex entity by the newly formed amido ligand. In his book the amido dicobalt complex of Fig. 2 is still denoted as unpublished results. It was apparently obtained by the, at Werner's time particularly exotic, reaction of an ammine complex dissolved in liquid ammonia! As we know nowadays the postulated dinuclear complex $\left[\left(\mathrm{NH}_{3}\right)_{5} \mathrm{CoNH}_{2} \mathrm{Co}\left(\mathrm{NH}_{3}\right)_{5}\right] \mathrm{X}_{5}$ is fairly stable, can be isolated and has been structurally characterized. ${ }^{[4]}$ Other examples are 'ol complexes' in Alfred Werner's termi- nology bearing bridging $\mathrm{OH}$ groups, which are as singly bridged complexes quite rare species, but are common bridging units in multiply bridged complexes. Single bridges hold metal centers less strongly together than doubly or even triply bridged ones, which provide cohesion to the connected metals with an increasing number of bridging units. Another circumstance may also come into play favoring multiple bonding of bridging atoms. For instance, multiple bonding of complexes with proton-bearing ammine-derived ligands in bridging position (Komplexe Metallammoniake) can easily be induced by removal of $\alpha$-protons from these ligand groups. Any $\alpha$-proton of ammine or amine moieties become strongly acidified upon metal coordination and two metals are expected to acidify such protons to an even higher extent so that bridging ligands may be (kinetically or thermodynamically) more acidic than terminal ones so that an extraordinary tendency to form prototopic species results.

Alfred Werner mentions in his book the exemplary formation of the $\left[\mathrm{I}\left(\mathrm{NH}_{3}\right)_{3} \mathrm{Pt}(\mu-\right.$ $\left.\left.\mathrm{NH}_{2}\right)_{2} \mathrm{Pt}\left(\mathrm{NH}_{3}\right)_{3} \mathrm{I}\right] \mathrm{X}_{4}$ (I, Fig. 3), ${ }^{[1 \mathrm{~b}]}$ a dinuclear amido bridged complex, which had been obtained by elimination of HI from
$\left[\mathrm{PtI}_{2}(\mathrm{IV})\left(\mathrm{NH}_{3}\right)_{4}\right] \mathrm{X}_{2}$ complexes prepared in the quite early days of coordination chemistry by $\mathrm{Cleve}^{[5]}$ and Jörgensen. ${ }^{[6]}$

Alfred Werner describes then in addition that complex I can be deprotonated further to the doubly bridged imido complex II (Fig. 3) emphasizing the abovementioned general fact that proton-bearing bridging ligands may be more acidic than terminal ones and are expected to undergo preferential deprotonation. It should however be mentioned that the iodide complexes $\mathbf{I}$ and II $(\mathrm{X}=\mathrm{I})$ have not been studied in more recent literature. I and II look like stable molecules, but whether they really are stable can presently not be stated with certainty and the given structures I and II may not be correctly assigned as products of the given synthetic routes. Nevertheless, they are highly plausible and quite instructive molecules even in view of subsequent decades of chemistry knowledge and the 'good guesses' of Alfred Werner undoubtedly witness his extraordinary ability of intuition.

Contemporary studies of such diplatinum complexes revealed the existence of prototopic bridged structures. Applying as a starting point the core of the $\left[\left(\mathrm{NH}_{3}\right)_{4} \mathrm{Pt}(\mu-\right.$



Fig. 2. Alfred Werner's conclusions by analogy deriving formation of bridged complexes (Komplexe Metallammoniake) from dimethyl amine by comparison of these to methane and hexammine cobalt salts (Einfache Metallammoniake), the later viewed as stable and saturated entities. See for instance, 'Neuere Anschauungen auf dem Gebiete der anorganischen Chemie', second edition, p. 186. ${ }^{[2 b]}$
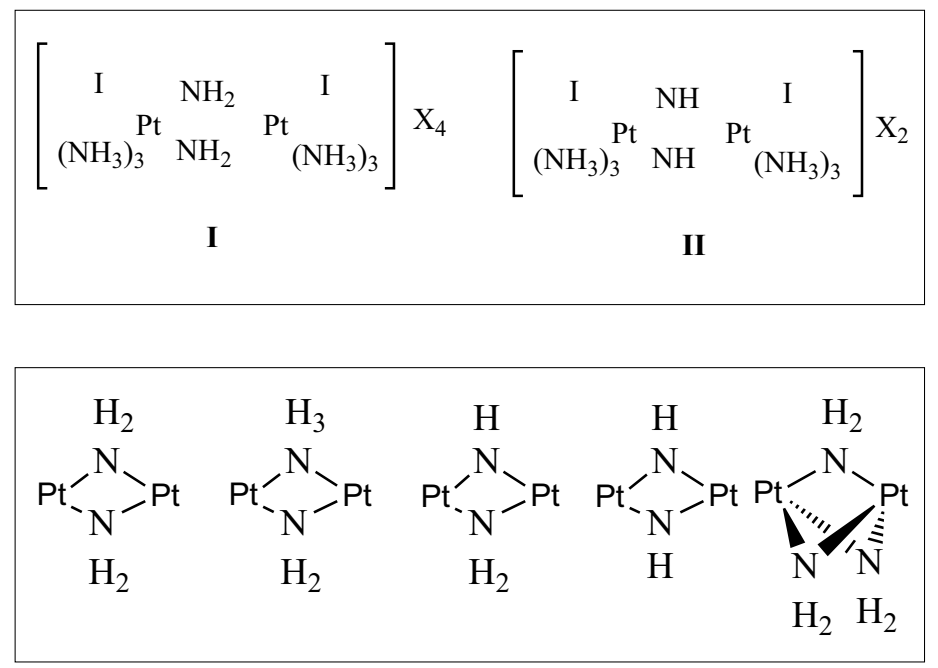

Fig. 3. Reproduction of platinum amidoand imido-bridged strucutres of complexes displayed in the second edition of Alfred Werner's book, p.190. [2b]

Fig. 4. Bridging cores of diplatinum moieties with prototopic $\mathrm{N}$ ligands as revealed by recent literature. ${ }^{[7]}$ 
$\left.\left.\mathrm{NH}_{2}\right)_{2} \mathrm{Pt}\left(\mathrm{NH}_{3}\right)_{4}\right] \mathrm{X}_{6}$ type complexes, we see that further deprotonations can occur to form $\mu^{2}$ - and $\mu^{3}$-bridged structures, ${ }^{[7]}$ as depicted in Fig. 4.

The description of these more recent findings makes one once again aware of the general fact that synthesis and structural elucidation of molecules is particularly difficult in the field of bridged compounds and requires highly sophisticated analytical tools. At Werner's time and before, the arsenal of analytical tools for such tasks was rather limited and maybe in one or the other case even too limited to arrive safely at definite and correct structural conclusions.

Alfred Werner's interest in multinuclear complexes (mehrkernige Metallammoniake) arose presumably in the period 1896-1897. Alfred Werner focused mainly on the exploration of cobalt(III) and chromium(III) compounds. ${ }^{[8]}$ His endeavors turned into quite intense studies later with many $\mathrm{PhD}$ students of his group involved in the field. He not only developed the chemistry of dinuclear complexes, but also that of tetranuclear 'ol' compounds, ${ }^{[9]}$ of which many turned out to be chiral and separable into enantiomers. Alfred Werner never left the area of multinuclear complex research and even after the appearance of illness, which suspended him from work, his dinuclear and polynuclear work was carried on by his assistant Paul Pfeiffer, who became his colleague later on.

This article analyzes in detail several dinuclear cobalt complexes from the Werner collection of original samples of the University of Zurich ${ }^{[10]}$ in order to examine their exact structures. These examples of complexes provide a wonderful demonstration of Werner's intuition. The 'tool' of chemical intuition played a major role at Werner's time in the prediction of the structures of such complexes. The selected examples of compounds were studied mainly by single-crystal X-ray diffraction using in an almost 'non-destructive' way a tiny fraction of the original material of the Werner group stored in vials (Fig. 5). Part of the investigations comprises examples of already published work from our group and another part comprises unpublished work demonstrating the great achievements of Alfred Werner.

Alfred Werner has indeed studied the chemistry of dinuclear complexes quite intensively, ${ }^{[11]}$ but some aspects of this chemistry remained unsolved or had necessarily to remain unsolved. A. G. Sykes et al. once expressed this circumstance in the following way: "A large number of binuclear complexes of cobalt were first prepared and identified by Werner around 1910 , but details of some of the reactions involved remained uncertain."[12] One of the challenges of this article was to trace such unresolved 'details' of dinuclear co-

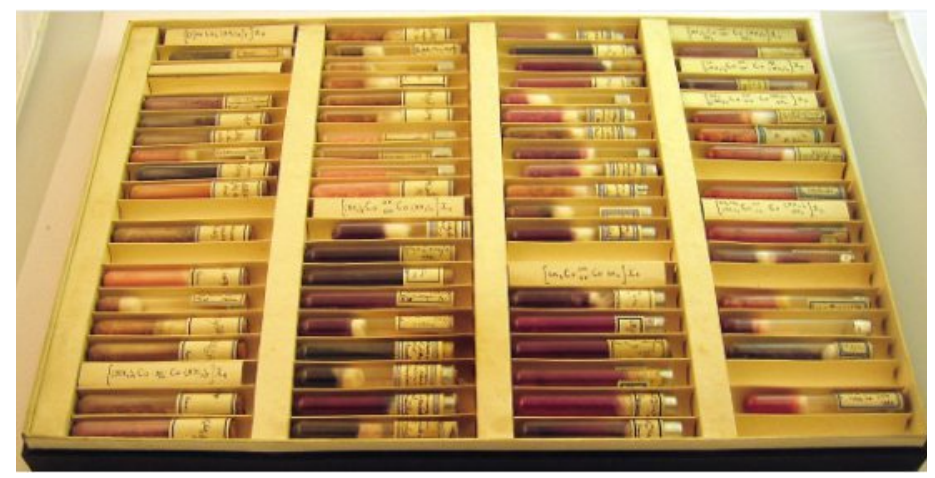

Fig. 5. Picture of an exemplary drawer of the cupboard of the 'Werner collection of samples' containing the original samples prepared by Alfred Werner's students.
3. Hexammin- $\mu$-amino-peroxo-ol-kobalte-kobaltisalze:

$$
\left.\left[\left(\mathrm{NH}_{8}\right)_{3} \mathrm{Co}: \underset{\mathrm{O}_{2}}{\mathrm{OH}}: \mathrm{Co}\left(\mathrm{NH}_{8}\right)_{3}\right] \mathrm{X}_{3}{ }^{1}\right) .
$$

Eine von dieser Verbindungsreihe derivierende Chlororeihe findet sich im rohen Melanochlorid, und durch Umsatz des letzteren mit Silbernitrat erhält man deshalb neben dem Nitrat der Reihe 4, 1, auch das Nitrat der vorliegenden Reihe, aus dem andere Salze dargestellt werden können. Salze dieser Verbindungsreihe entstehen ferner, wenn die Oktarnmin- $\mu$-peroxo-amino-kobaltekobaltisalze in wässeriger Lösung mit Chlorammonium erhitzt werden :

$$
\begin{aligned}
& {\left[\left(\mathrm{H}_{3} \mathrm{~N}\right)_{4} \stackrel{\mathrm{Mo}}{\mathrm{Co}} \cdot \mathrm{O}_{2} \cdot \mathrm{No}\left(\mathrm{N} \mathrm{H}_{3}\right)_{4}\right] \mathrm{X}_{4}+\mathrm{H}_{2} \mathrm{O}}
\end{aligned}
$$

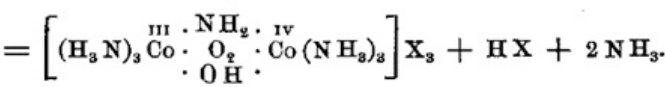

Die Salze haben intensiv grüne Farbe und reagieren gegen Lackmus neutral.

balt complex chemistry and to 'examine' Alfred Werner's ability of intuition in his attempts to reach definite conclusions. Some of the problems, which he and his coworkers had to tackle, will be described in the forthcoming sections 3 and 4 .

\section{Marie Scanavy-Grigorieff's Work on Dinuclear $\left[\mathrm{Co}_{2}\left(\mathrm{NH}_{3}\right)_{6}\left(\mu-\mathrm{NH}_{2}\right)\right.$ $\left.(\mu-\mathrm{OH})\left(\mu-\mathrm{O}_{2}\right)\right] \mathrm{X}_{3}$ complexes}

The triply-bridged hexammine $(\mu$ amido)( $\mu$-hydroxo)( $\mu$-superoxo)dicobalt complex, $\quad\left[\mathrm{Co}_{2}\left(\mathrm{NH}_{3}\right)_{6}\left(\mu-\mathrm{NH}_{2}\right)(\mu-\mathrm{OH})\right.$ $\left.\left(\mu-\mathrm{O}_{2}\right)\right]\left(\mathrm{NO}_{3}\right)_{3}$, constitutes indeed a paramount problem of structural elucidation. But Marie Scanavy-Grigorieff and Alfred Werner did an unbelievably good job in the structural assignment of this complex finding correctly subtle details of its structure, which are enormously hard to unravel, even using sophisticated modern analytical instrumentation. Marie Scanavy-Grigorieff prepared the $\left[\mathrm{Co}_{2}\left(\mathrm{NH}_{3}\right)_{6}\left(\mu-\mathrm{NH}_{2}\right)(\mu-\mathrm{OH})\right.$ $\left.\left(\mu-\mathrm{O}_{2}\right)\right] \mathrm{X}_{3}$ complex by a rather sophisticated route as described in her $\mathrm{PhD}$ thesis and by Alfred Werner in publications. ${ }^{[13]}$ In his book 'Neuere Anschauungen auf dem Gebiete der anorganischen Chemie',[2b] Alfred Werner summarizes the access to these compounds as depicted in Fig. 6.

Alfred Werner describes in the text shown in Fig. 6 the 'Konstitution' (constitution) of these compounds correctly, but he named this compound a $\mu$-peroxo species, which was eventually found to be in modern terms a superoxo compound. The superoxo anion was not known at his time, so how could he have assigned it as such? Werner indeed realized the detail that there were two kinds of cobalt centers as indicated in the formulae of Fig. 6 designated to possess $\mathrm{Co}(\mathrm{III})$ and $\mathrm{Co}(\mathrm{IV})$ oxidation states, which are correct assignments if the $\mathrm{O}_{2}$ bridge is counted as a peroxo ligand. But even on the hand-written label of the vial of this complex from the Werner collection, ${ }^{[10]}$ Alfred Werner distinguished the binding of the cobalt atoms to each of the oxygen atoms of the superoxo bridging unit (Fig. 7). That is what one might call 'superintuition'!

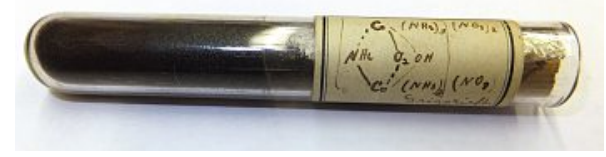

Fig. 7. Photograph of the vial of the $\left[\mathrm{Co}_{2}\left(\mathrm{NH}_{3}\right)_{6}\left(\mu-\mathrm{NH}_{2}\right)(\mu-\mathrm{OH})\left(\mu-\mathrm{O}_{2}\right)\right]\left(\mathrm{NO}_{3}\right)_{3}$ complex from the Werner collection. The formula on the label indicates different binding of the $\mu-\mathrm{O}_{2}$ ligand to the cobalt atoms expressed in Alfred Werner's hand drawing by a straight and a dotted line. 
In a contemporary $\mathrm{X}$-ray diffraction study on a crystal of the $\left[\mathrm{Co}_{2}\left(\mathrm{NH}_{3}\right)_{6}(\mu-\right.$ $\left.\left.\mathrm{NH}_{2}\right)(\mu-\mathrm{OH})\left(\mu-\mathrm{O}_{2}\right)\right] \quad\left(\mathrm{NO}_{3}\right)_{3}$ compound from our and $\mathrm{S}$. Lippard's group, ${ }^{[14]}$ the $\mathrm{Co}-\mathrm{O}$ distances were found to be different, indeed, amounting to $1.872(3)$ and 1.887(3) A.

\section{Alfred Werner's Intuition in the Field of Dinuclear Ammine- based Complexes 'Mehrkernige Metallammoniake' Prepared from $\left[\mathrm{Co}_{2}\left(\mathrm{NH}_{3}\right)_{6}(\mu-\mathrm{OH})_{3}\right] \mathrm{X}_{3}$ Complexes, the 'tri-ol' Bridged Dinuclears}

Following again Alfred Werner's book (for instance ref. [2c]) as a descriptive guideline, it tells us much about the use of bridged 'tri-ol' complexes ( $\mu$-trihydroxy) as a chemical base for further substitution of the bridges of dinuclear complexes. We tried to pursue this chemistry, as reported in the excerpt of his book in Fig. 8, by studying original samples of his PhD students stored in the above-mentioned collection of original samples. ${ }^{[10]}$ The great problem for Alfred Werner was to assign the nature of the bridges and we will see how he dealt with these difficulties by a thorough analysis of the test examples based on the application of single-crystal $\mathrm{X}$-ray diffraction studies.

Alfred Werner describes in the chapter on 'Dreikernige Metallammoniaksalze' (Fig. 8) how dinuclear complexes ('dikernige Metallammoniake') are obtained from the base compounds, the 'tri-ols' $\left(\left[\mathrm{Co}_{2}\left(\mathrm{NH}_{3}\right)_{6}(\mu-\mathrm{OH})_{3}\right] \mathrm{X}_{3}\right)$ when acidified with acids of potentially bridge-building anions. We studied the cases of the triply bridged $\mu$-acetato and $\mu$-nitro dihydroxy and of di( $\mu$-acetato) hydroxy dicobalt complexes. The PhD students E. Bindschedler (PhD thesis, 1901[15]) and E. Welti (PhD thesis 1910[16]) were involved in tackling the acetato chemistry and E. Bindschedler together with A. Grün (PhD thesis $1901^{[17]}$ ) were to collaborate in the field of $\mu$-nitrito complexes. Despite the fact that Bindschedler and Welti and Bindschedler and Grün shared the same field in their PhD works, Bindschedler and Welti were separated by a great difference in time, which emphasizes the strong and long-lasting interest of Alfred Werner in this chemistry, but also this circumstance may point to the fact that the assignment of bridged dinuclear structures was quite difficult, more than anticipated, and also more time consuming than the assignment of molecular structures in the field of mononuclear compounds. It may be speculated that intuition could not have helped greatly to speed up the process, because apparently the level of respective knowledge about such types of compounds
Dreikernige Metallsmmoniaksalze.

Salpetrige Säure erzeugt aus den Hexammintriolsalzen Salze der Hexammin- $\mu$-nitro-diol-dikobaltireihe:

$$
\begin{aligned}
& {\left[\left(\mathrm{H}_{3} \mathrm{~N}\right)_{3} \mathrm{CoH}\right.} \\
& \mathrm{OH} \\
& {\left[\left(\mathrm{H}_{3} \mathrm{~N}\right)_{3} \mathrm{Co} \underset{\left(\mathrm{N}_{2}\right)}{\mathrm{OH}} \mathrm{OH}\left(\mathrm{NH}_{3}\right)_{3}\right] \mathrm{X}_{3}+\mathrm{H}_{2} \mathrm{O}}
\end{aligned}
$$

Diese Verbindungsreihe enthält die salpetrige Säure in außerordentlich fester Bindung. Führt man noch eine zweite Nitrogruppe ein, so entstehen Hexammin- $\mu$-dinitro-ol-dikobaltisalze:

$$
\left.\left[\left(\mathrm{H}_{3} \mathrm{~N}\right)_{3} \mathrm{Co}<\underset{\left(\mathrm{NO}_{2}\right)}{\mathrm{OH}}\right) \mathrm{Co}\left(\mathrm{NH}_{3}\right)_{3}\right] \mathrm{x}_{3} \text {. }
$$

5. Hexammin- $\mu$-acetato-diol-dikobaltisalze $\left.{ }^{1}\right)$ :

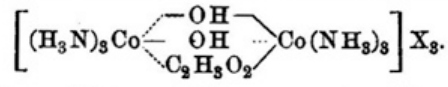

Diese wichtigen Salze entstehen aus den Hexammintriolsalzen durch Einwirkung von Essigsäure. Die Salze sind rot gefärbt und zeichnen sich durch feste Bindung des Essigsäurerestes aus.

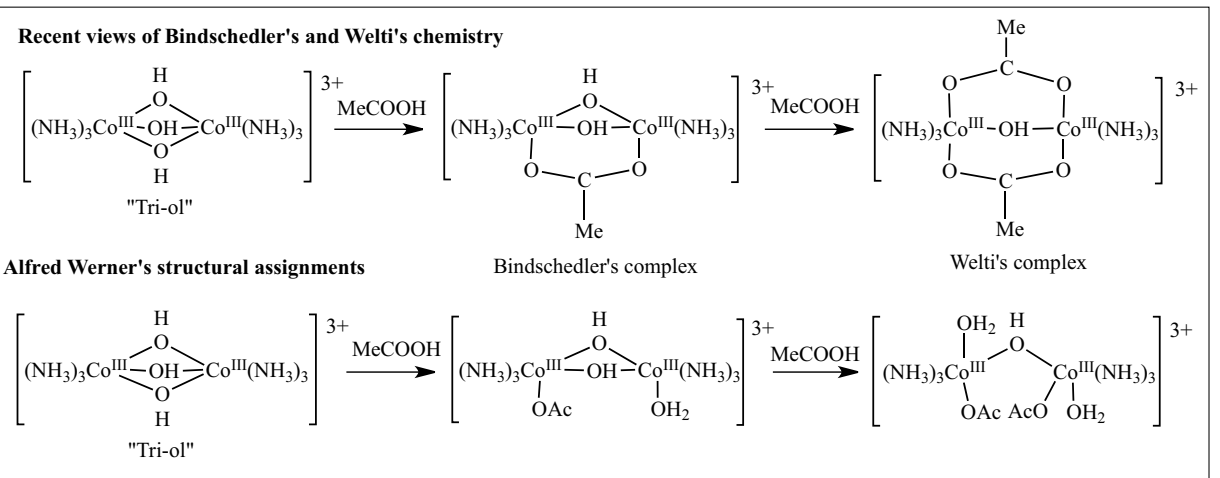

Scheme 1. Top: Bindschedler's and Welti's reactions replacing $\mu-\mathrm{OH}$ bridges of the 'tri-ol' complex by acetate to give mono- and di- $\mu$-acetato species. Structural assignment's based on recent time's methodologies. Bottom: Werner's structural assignment of the Bindschedler and Welti complexes as terminal $\eta^{1}$ mono- and diacetato aqua complexes. $A c=C(O) M e$.

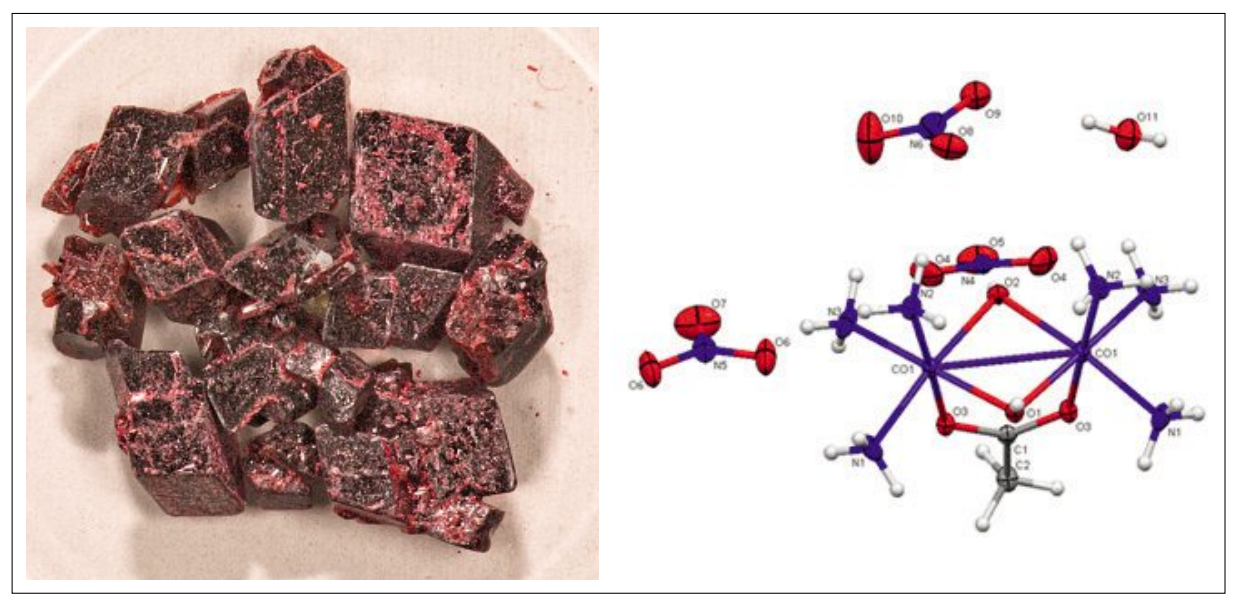

Fig. 9. Left: Photograph of Bindschedler's $\left[\mathrm{Co}_{2}\left(\mathrm{NH}_{3}\right)_{6}(\mu-\mathrm{OH})_{2}\left(\mu-\mathrm{O}_{2} \mathrm{CMe}\right)\right]\left(\mathrm{NO}_{3}\right)_{3} \cdot \mathrm{H}_{2} \mathrm{O}$ crystals. Right: Structural model of the X-ray diffraction study of Bindschedler's complex $\left[\mathrm{Co}_{2}\left(\mathrm{NH}_{3}\right)_{6}(\mu-\mathrm{OH})_{2}(\mu-\right.$ $\left.\left.\mathrm{O}_{2} \mathrm{CMe}\right)\right]\left(\mathrm{NO}_{3}\right)_{3} \cdot \mathrm{H}_{2} \mathrm{O}$.

was relatively low at the given time. In the following chapters some nice examples of enigmatic $\mu$-acetate and $\mu$-nitrito complexes from the Werner group are discussed in the spirit of a comparison of the structural assignments at Alfred Werner's time with contemporary assignments.

\subsection{The Acetate Puzzle of $\left[\mathrm{Co}_{2}\left(\mathrm{NH}_{3}\right)_{6}(\mu-\mathrm{OH})_{n}\left(\mu-\mathrm{O}_{2} \mathrm{CMe}\right)_{3-n}\right] X_{3}$ Complexes $(n=1,2)$}

Starting from the 'tri-ol' complex E. Bindschedler had actually succeeded in the reaction shown at the top of Scheme 1 , replacing one $\mu$-hydroxy by a $\mu$-acetato 
group in the presence of acetic acid. He produced a nicely crystalline compound as depicted in Fig. 9, left, and confirmed by recent structure determination shown in Fig. 9, right.

The crystals of Bindschedler's complex (Fig. 9, left) were suitable for an X-ray diffraction study. They apparently had not suffered from about 100 years' of storage. According to the recent structure determination, Werner and Bindschedler's proposition of a $\eta^{1}$-acetato aqua dicobalt structure turned out to be incorrect (Scheme 1, bottom reaction).

According to the proposal in Scheme 1, top reaction, a $\mu^{2}$-acetato group was found and no aqua ligand in the primary coordination spheres of the cobalt centers (see Fig. 9, right). Already in $1910 \mu^{2}$-acetato ligands could have been considered as a plausible alternative for bridges in cationic dicobalt structures. Alfred Werner apparently did not take this binding mode into consideration, as depicted in Scheme 1, bottom reaction. Later on Alfred Werner might have changed his view, since in the 4th edition of his book stemming from 1920 he drew a structure indicating a bridging $\mu$-acetato unit (see Fig. 8). Our structure determination revealed the presence of solvate water in the crystal lattice. The presence of the water molecule, certainly detected by Bindschedler's analytical study, may have deluded E. Bindschedler and A. Werner to assume an aqua ligand incorporated in the coordination sphere. The elemental compositions of Bindschedler and Werner's proposition of a $\left[\mathrm{Co}_{2}\left(\mathrm{NH}_{3}\right)_{6}(\mu-\mathrm{OH})_{2}\left(\mathrm{H}_{2} \mathrm{O}\right)\left(\eta^{1}-\mathrm{O}_{2} \mathrm{CMe}\right)\right]$ $\left(\mathrm{NO}_{3}\right)_{3}$ complex and of the observed structure of the Bindschedler $\left[\mathrm{Co}_{2}\left(\mathrm{NH}_{3}\right)_{6}(\mu\right.$ $\left.\mathrm{OH})_{2}\left(\mu-\mathrm{O}_{2} \mathrm{CMe}\right)\right]\left(\mathrm{NO}_{3}\right)_{3} \cdot \mathrm{H}_{2} \mathrm{O}$ complex are indeed the same. The proposed structure in Scheme 1 is thus to be very close to the real structure in Fig. 9, right, something like an 'isomer' in the solid state. It should be mentioned at this point that the structure of a related dicobalt complex $\left[\mathrm{Co}_{2}\left(\mathrm{NH}_{3}\right)_{6}(\mu-\right.$ $\left.\mathrm{OH})_{2}\left(\mu-\mathrm{O}_{2} \mathrm{CMe}\right)\right] \mathrm{Br}_{3} \cdot 3 \mathrm{H}_{2} \mathrm{O}$ with bromides as counterions has been described in the literature ${ }^{[18]}$ confirming the tris-bridged structure of Bindschedler's molecule.

Subsequently, almost ten years later PhD student E. Welti studied the reaction of Bindschedler's complex with acetic acid, which revealed formation of the disubstituted $\mu$-acetato product $\left[\mathrm{Co}_{2}\left(\mathrm{NH}_{3}\right)_{6}(\mu\right.$ $\left.\mathrm{OH})\left(\mu-\mathrm{O}_{2} \mathrm{CMe}\right)_{2}\right]\left(\mathrm{NO}_{3}\right)_{3} \cdot \mathrm{H}_{2} \mathrm{O}$ as depicted in Scheme 1, top reaction.

But the structure given on the label of the vial shown in Fig. 10 is the structure of the monoacetato aqua complex (Scheme 1 , bottom equation). Apparently the compound in the vial is different from the structure drawn on the label. Taking Alfred Werner's book 'Neuere Anschauungen auf dem Gebiete der anorganischen Chemie'

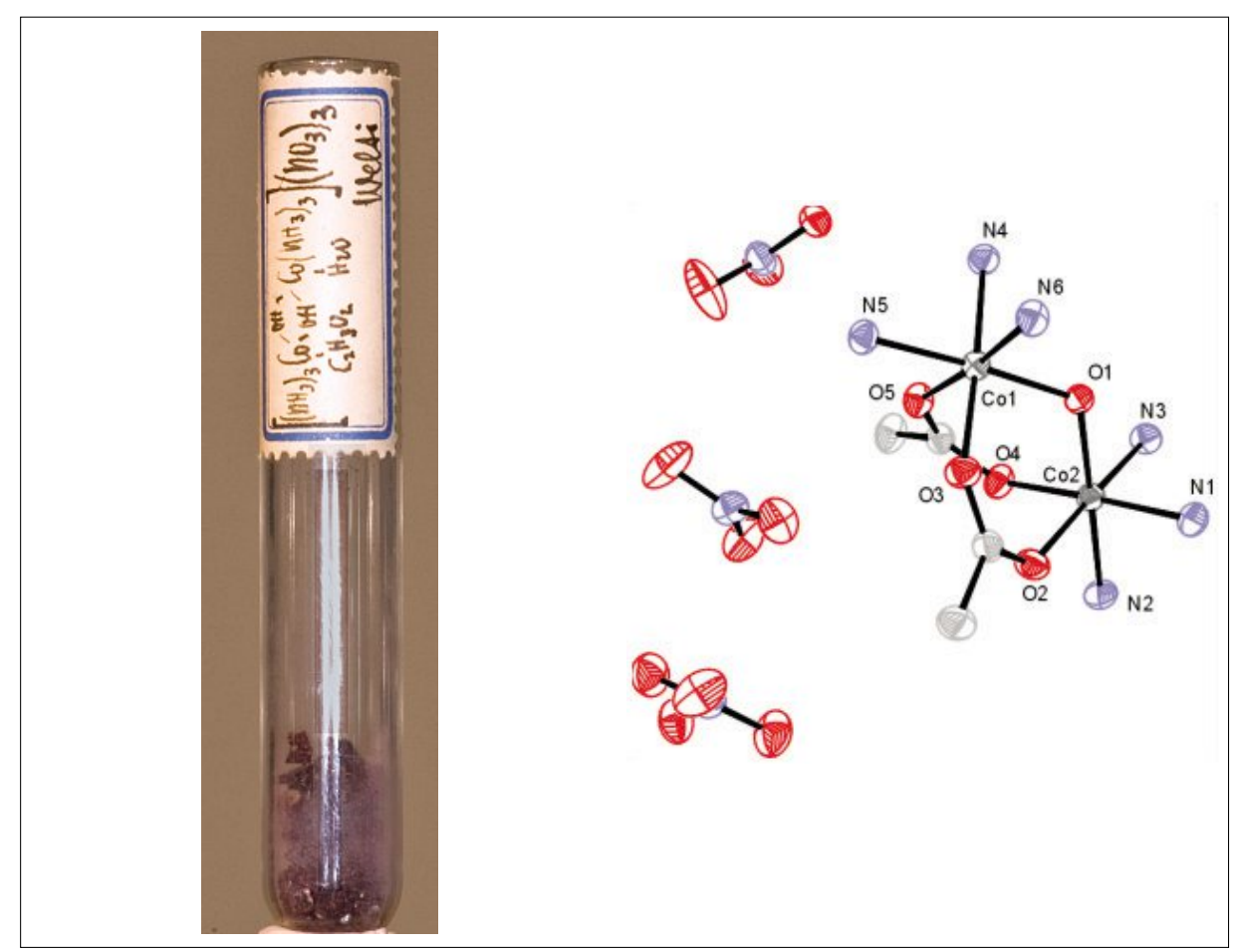

Fig. 10. Left: Photograph of the vial of Welti's complex $\left[\mathrm{Co}_{2}\left(\mathrm{NH}_{3}\right)_{6}(\mu-\mathrm{OH})\left(\mu-\mathrm{O}_{2} \mathrm{CMe}\right)_{2}\right]\left(\mathrm{NO}_{3}\right)_{3} \cdot \mathrm{H}_{2} \mathrm{O}$ from the Werner collection. Right: Structural model of the X-ray diffraction study of Welti's $\mu$-disubstituted acetato complex $\left[\mathrm{Co}_{2}\left(\mathrm{NH}_{3}\right)_{6}(\mu-\mathrm{OH})\left(\mu-\mathrm{O}_{2} \mathrm{CMe}\right)_{2}\right]\left(\mathrm{NO}_{3}\right)_{3} \cdot \mathrm{H}_{2} \mathrm{O}$ crystallizing as a mono hydrate (water molecule not shown). $\mathrm{H}$ atoms are omitted.

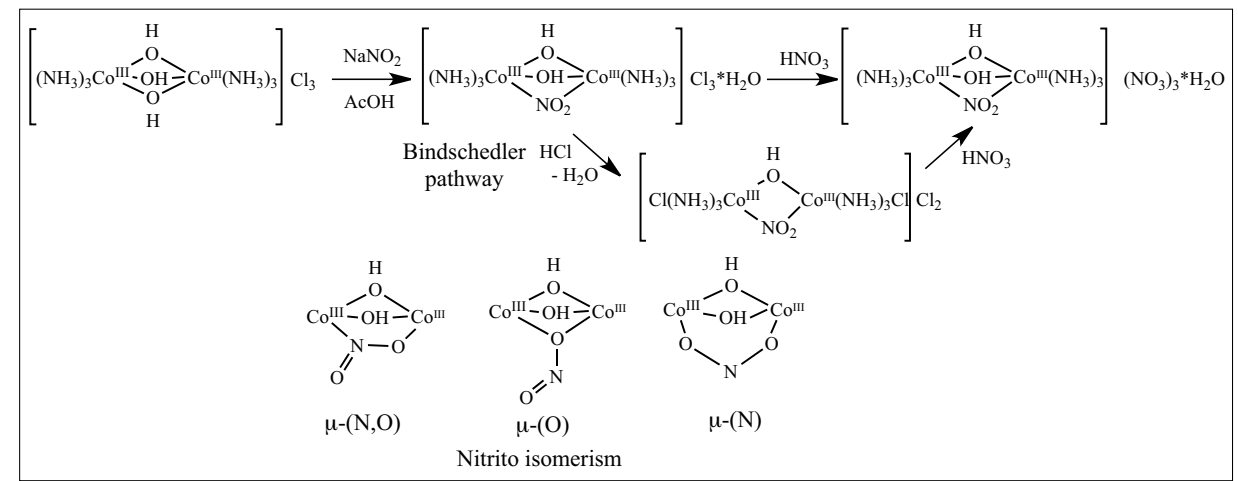

Scheme 2. Top: Preparation of mono nitrito complexes from $\mu$-trihydroxy cobalt ('tri-ol') starting complexes via a bridge substitution reaction with nitrous acid and subsequent nitrate anion exchange. As described on the label of the vial by E. Bindschedler (see Fig. 11, top) he pursued a somewhat different pathway via the 'Chloronitritoditriamminkobaltchlorid' complex. Bottom: Various structural isomers of $\mu$-nitrito bridges in dihydroxy $\left(\mu-\mathrm{NO}_{2}\right)$ cobalt compounds.

as a reference, for instance, the 4th and last edition that he still could have edited, on $\mathrm{p}$. 283[2d] (see also the excerpt in Fig. 8), we have to assume that Alfred Werner was not aware of the existence of a $\mu$-diacetato dicobalt complex, since he never mentioned this compound in his compendium-like compilations. In Welti's $\mathrm{PhD}$ thesis the given structure from Scheme 1 was however mentioned. The structure determination of the $\left[\mathrm{Co}_{2}\left(\mathrm{NH}_{3}\right)_{6}(\mu-\mathrm{OH})\left(\mu-\mathrm{O}_{2} \mathrm{CMe}\right)_{2}\right]$ $\left(\mathrm{NO}_{3}\right)_{3} \cdot \mathrm{H}_{2} \mathrm{O}$ complex revealed again the presence of a solvate water molecule, which would for Welti's complex as for Bindschedler's compound have justified the postulation of an aqua ligand.

We could therefore summarize that in this realm of $\mu$-acetato complexes, the re- liability of modern structure determination brought some 'order' into the confusing situation of such compounds in the Werner collection.

\subsection{The Nitrito Mystery of $\left[\mathrm{Co}_{2}\left(\mathrm{NH}_{3}\right)_{6}(\mu-\mathrm{OH})_{n}\left(\mu-\mathrm{NO}_{2}\right)_{3-n}\right] \mathrm{X}_{3}$ Complexes $(n=1,2)$}

Bindschedler's PhD thesis not only contains work on bridged acetato complexes, but also nitro or nitrito complexes, such as those shown in Scheme 2. Alfred Werner describes in his book ${ }^{[2 \mathrm{~d}]}$ that synthetic access to mono- and disubstituted nitrito compounds $\left[\mathrm{Co}_{2}\left(\mathrm{NH}_{3}\right)_{6}(\mu-\mathrm{OH})_{n}(\mu-\right.$ $\left.\left.\mathrm{NO}_{2}\right)_{3-\mathrm{n}}\right] \mathrm{X}_{3}(\mathrm{n}=1,2)$ is possible (Fig. 8).

Assuming the incorporation of one nitrito ligand, interesting questions arise 

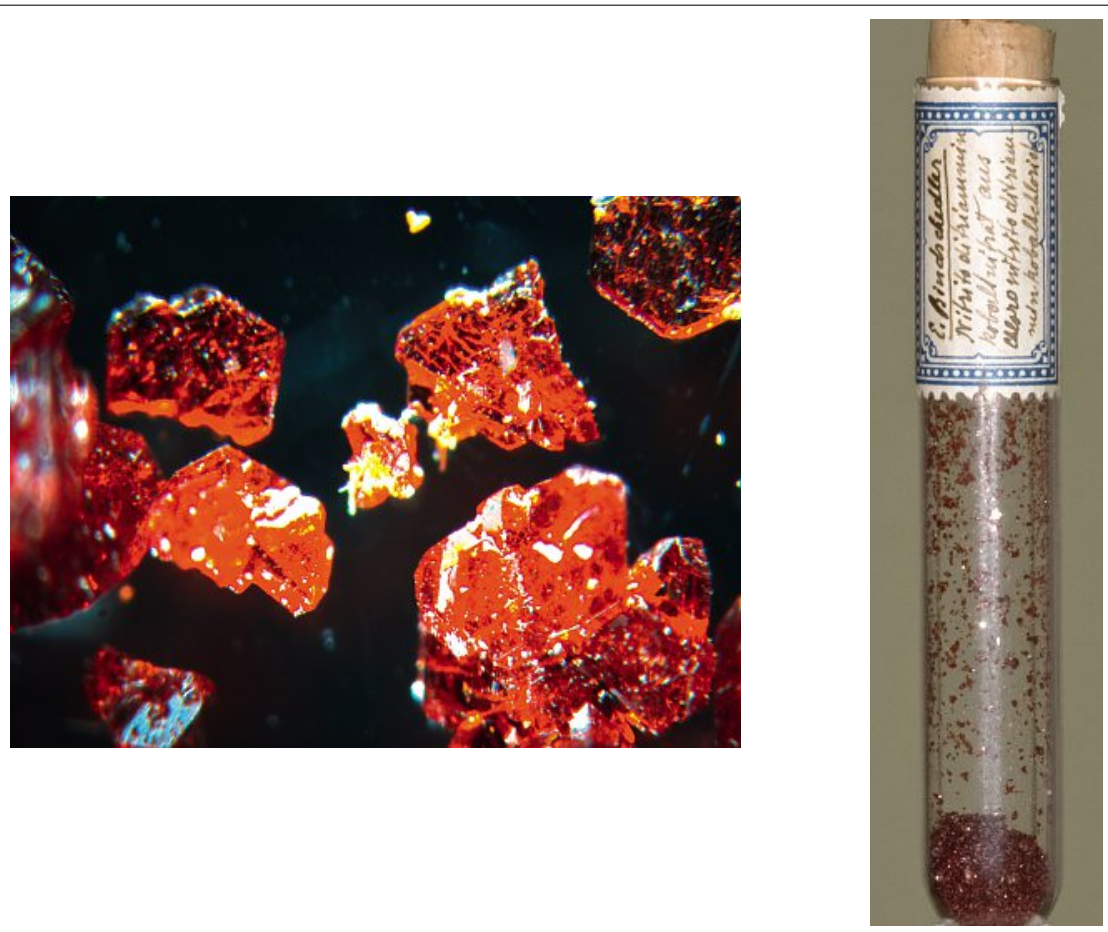

Fig. 11. Right: E. Bindschedler's vial reporting on the label the product of the intended conversion of 'Chloronitritoditriamminkobaltchlorid' with nitrous acid (not mentioned, but essential in the given reaction) to yield 'Nitritoditriamminkobaltnitrat'. According to the $\mathrm{X}$-ray diffraction analysis of Fig. 9 the vial contains the mono $\mu$-nitrito $\mu$-dihydroxy species $\left[\mathrm{Co}_{2}\left(\mathrm{NH}_{3}\right)_{6}(\mu-\mathrm{OH})_{2}\left(\mu-\mathrm{O}_{2} \mathrm{~N}\right)\right]$ $\left(\mathrm{NO}_{3}\right)_{3} \cdot \mathrm{H}_{2} \mathrm{O}$. Left: Microscopic picture of the crystals of $\left[\mathrm{Co}_{2}\left(\mathrm{NH}_{3}\right)_{6}(\mu-\mathrm{OH})_{2}\left(\mu-\mathrm{O}_{2} \mathrm{~N}\right)\right]\left(\mathrm{NO}_{3}\right)_{3} \cdot \mathrm{H}_{2} \mathrm{O}$ contained in the vial.

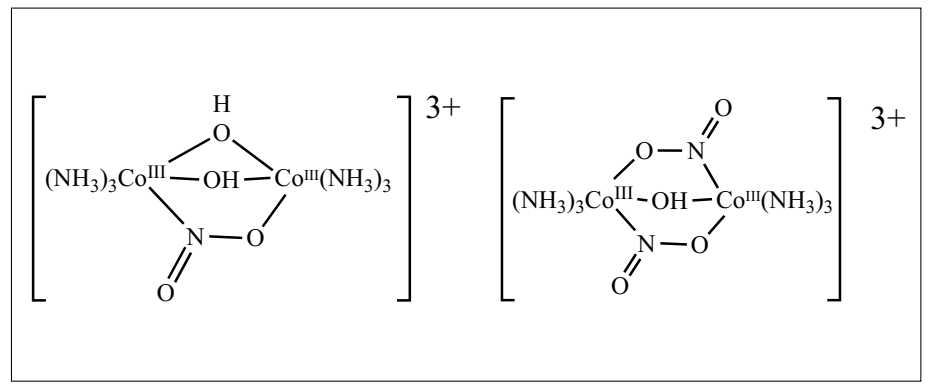

Fig. 12. The true core structures of the cationic mono- and disubstituted nitrito, $\mu$-hydroxy dicobalt complexes of the type $\left[\mathrm{Co}_{2}\left(\mathrm{NH}_{3}\right)_{6}\right.$ $\left.(\mu-\mathrm{OH})_{n}\left(\mu-\mathrm{NO}_{2}\right)_{3-n}\right] X_{3}$ $(n=1,2)$ revealing $\mu(\mathrm{N}, \mathrm{O})$-nitrito structures.

based on current knowledge. We expected uncertainty in the assignment of the number of nitrito bridges of the two cobalt centers (mono $(\mu$-nitrito) vs di( $\mu$-nitrito $))$ and in the nitrito-bridging mode $(\mu-\mathrm{O}, \mu-\mathrm{N}$ or $\mu-\mathrm{N}, \mathrm{O})$ (see respective publication ${ }^{[19]}$ ).

How could Alfred Werner and E. Bindschedler and also his successor as a $\mathrm{PhD}$ student in Werner's group, A. Grün, have guessed the binding modes of a bridging nitrito group without the help from (modern) spectroscopic methods? The early 20th century approach for the assignment of chemical structures was not an easy and safe way to eventually reach the right conclusion of the presence of a $\mu-(\mathrm{N}, \mathrm{O})$ nitrito ligand, even if Alfred Werner's exceptional intuition might have been involved. Only more recent accuracy in spectroscopic and diffractive structure determination methodologies allow predictions capable of assigning the precise molecular structures of the $\left[\mathrm{Co}_{2}\left(\mathrm{NH}_{3}\right)_{6}(\mu-\right.$ $\left.\mathrm{OH})_{\mathrm{n}}\left(\mu-\mathrm{O}_{2} \mathrm{~N}\right)_{3-\mathrm{n}}\right]^{3+}$ cations.
In recent years the structures of the mono- and disubstituted complexes $\left[\mathrm{Co}_{2}\left(\mathrm{NH}_{3}\right)_{6}(\mu-\mathrm{OH})_{n}\left(\mu-\mathrm{NO}_{2}\right)_{3-\mathrm{n}}\right] \mathrm{X}_{3} \quad(\mathrm{n}=$ $1,2)$ could be derived by spectroscopic means ${ }^{[20,21]}$ (Fig. 12). For the disubstituted $\mu$-nitrito structure an X-ray diffrac-

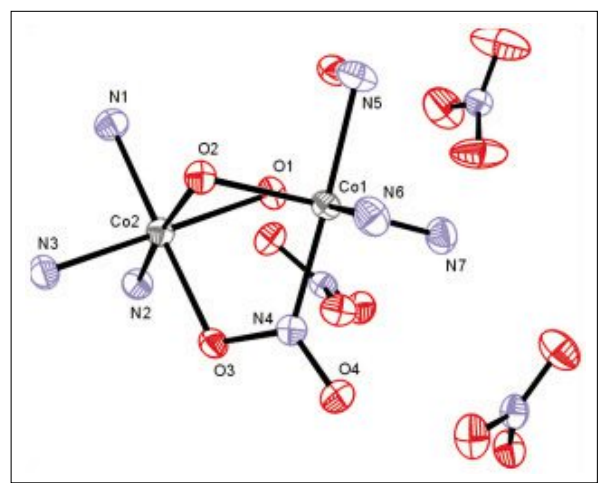

Fig. 13. Structural model of the $\left[\mathrm{Co}_{2}\left(\mathrm{NH}_{3}\right)_{6}\right.$ $\left.(\mu-\mathrm{OH})_{2}\left(\mu-\mathrm{O}_{2} \mathrm{~N}\right)\right]\left(\mathrm{NO}_{3}\right)_{3} \cdot \mathrm{H}_{2} \mathrm{O}$ complex revealing the presence of one nitrito bridge. The hydrate molecule and the $\mathrm{H}$ atoms are omitted. tion study (Fig. 13) was carried out that revealed the $\mu^{2}$-nitrito constitution of the complex and in addition the nitrito bridge's structural parameters.[21] These studies provided ample evidence for the preference of $\mathrm{NO}_{2}$ ligands to form in dicobalt complexes $\mu(\mathrm{N}, \mathrm{O})$ bridges.

\section{Concluding Remarks}

This article has pursued the main goal of demonstrating Alfred Werner's great predictive abilities in coordination chemistry supported by his prepared mind via intuition and in addition via his great base of knowledge. Examples for this notion were chosen from structural assignments of the tris-bridged dicobalt hexammine complex series constituting quite complex and difficult molecules in this respect. In Alfred Werner's endeavors of synthesis design and structural elucidation, his conceptual thinking helped strongly to guide his way. Alfred Werner's thoughtful valency concept, even though maybe physically not on solid ground, but with consistency in itself showed in many cases of complexes - chosen in this article as testimonies of Werner's intuition - that the prediction and elucidation of molecular structures could be carried out correctly or 'almost' correctly. Alfred Werner's intuition may also be felt when sitting in one of Alfred Werner's remaining chairs (Fig. 14) at the University of Zurich. A gentle warning is however expressed that there should not be too great hopes that the ability of intuition would in an act of inspiration be 'beamed over' to the person sitting in the chair. Too many of us have tried this without success.

\section{Experimental Section}

\subsection{X-ray Diffraction Analyses}

Single-crystal X-ray diffraction data were collected at 183(2) K on an Agilent Technologies Xcalibur Ruby area-detector diffractometer using a single wavelength

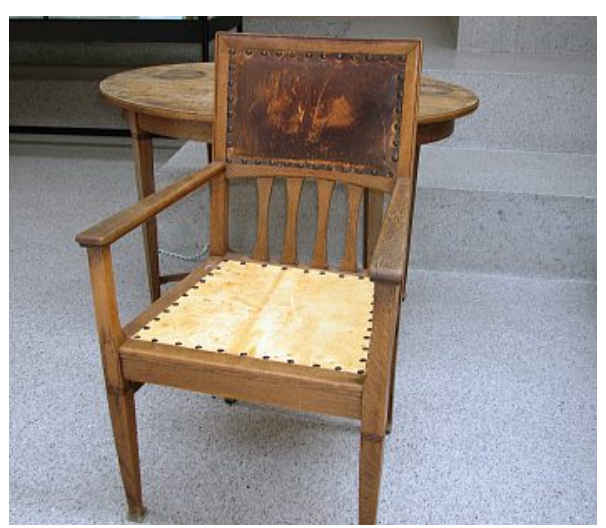

Fig. 14. One of Alfred Werner's chairs (remodeled) on exhibition at the University of Zurich. 
Table 1. Crystallographic data.

\begin{tabular}{|c|c|c|c|}
\hline $\begin{array}{l}\text { CCDC } \\
\text { empirical formula } \\
\text { formula weight }\left(\mathrm{g} \cdot \mathrm{mol}^{-1}\right)\end{array}$ & 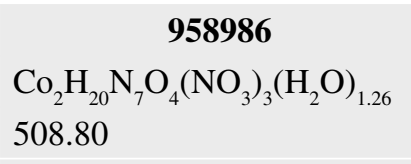 & \begin{tabular}{l}
\multicolumn{1}{c}{958987} \\
$\mathrm{C}_{2} \mathrm{H}_{23} \mathrm{Co}_{2} \mathrm{~N}_{6} \mathrm{O}_{4}\left(\mathrm{NO}_{3}\right)_{3}\left(\mathrm{H}_{2} \mathrm{O}\right)$ \\
517.17
\end{tabular} & $\begin{array}{l}\text { 958988 } \\
\mathrm{C}_{4} \mathrm{H}_{25} \mathrm{Co}_{2} \mathrm{~N}_{6} \mathrm{O}_{5}\left(\mathrm{NO}_{3}\right)_{3}\left(\mathrm{H}_{2} \mathrm{O}\right) \\
559.21\end{array}$ \\
\hline temperature $(\mathrm{K})$ & $183(2)$ & $183(2)$ & $183(2)$ \\
\hline wavelength ( $\AA$ ) & 0.71073 & 0.71073 & 0.71073 \\
\hline crystal system, space group & monoclinic, $P 2 / \mathrm{n}$ & monoclinic, $P 2_{1} / \mathrm{m}$ & monoclinic, $P 2 / \mathrm{n}$ \\
\hline$a(\AA)$ & $14.2922(6)$ & $7.2802(2)$ & $12.1484(12)$ \\
\hline$b(\AA)$ & $8.6591(3)$ & $11.1822(3)$ & 12.7053(3) \\
\hline$c(\AA)$ & $15.0167(6)$ & $11.1360(3)$ & $14.2771(11)$ \\
\hline$\alpha(\mathrm{deg})$ & 90 & 90 & 90 \\
\hline$\beta(\operatorname{deg})$ & $115.005(5)$ & $96.678(3)$ & $114.415(11)$ \\
\hline$\gamma(\mathrm{deg})$ & 90 & 90 & 90 \\
\hline volume $\left(\AA^{3}\right)$ & $1684.24(13)$ & $900.42(4)$ & $2006.6(3)$ \\
\hline $\mathrm{Z}$, density (calcd) $\left(\mathrm{Mg} \cdot \mathrm{m}^{-3}\right)$ & $4,2.006$ & $2,1.908$ & $4,1.851$ \\
\hline abs coefficient $\left(\mathrm{mm}^{-1}\right)$ & 2.065 & 1.930 & 1.744 \\
\hline$F(000)$ & 1042 & 532 & 1152 \\
\hline crystal size $\left(\mathrm{mm}^{3}\right)$ & $0.27 \times 0.23 \times 0.13$ & $0.41 \times 0.14 \times 0.03$ & $0.47 \times 0.38 \times 0.37$ \\
\hline$\theta$ range $(\mathrm{deg})$ & 2.59 to 30.51 & 2.59 to 30.51 & 2.87 to 30.51 \\
\hline reflections collected & 16030 & 8213 & 14989 \\
\hline reflections unique & $5147 /\left[R_{\mathrm{int}}=0.0390\right]$ & $2872 /\left[R_{\mathrm{int}}=0.0361\right]$ & $6127 /\left[R_{\mathrm{int}}=0.0236\right]$ \\
\hline completeness to $\theta(\%)$ & 100.0 & 99.9 & 99.9 \\
\hline absorption correction & analytical & analytical & analytical \\
\hline $\max / \min$ transmission & 0.800 and 0.648 & 0.935 and 0.578 & 0.647 and 0.548 \\
\hline data / restraints / parameters & 4083 / 6 / 296 & 2375 / 5 / 168 & $5455 / 3 / 288$ \\
\hline goodness-of-fit on $F^{2}$ & 1.029 & 1.056 & 1.048 \\
\hline final $R_{1}$ and $w R_{2}$ indices $[I>2 \sigma(I)]$ & $0.0352,0.0696$ & $0.0483,0.1158$ & $0.0285,0.0682$ \\
\hline$R_{1}$ and $w R_{2}$ indices (all data) & $0.0536,0.0769$ & $0.0612,0.1235$ & $0.0336,0.0704$ \\
\hline Largest diff. peak and hole $\left(\mathrm{e} . \AA^{-3}\right)$ & 0.438 and -0.471 & 1.241 and -0.437 & 0.806 and -0.624 \\
\hline
\end{tabular}

The unweighted $R$-factor is $R_{1}=\Sigma(F o-F c) / \Sigma F o ; l>2 \sigma(l)$ and the weighted $R$-factor is $w R_{2}=\left\{\Sigma w\left(F O^{2}-F c^{2}\right)^{2} / \Sigma w\left(F O^{2}\right)^{2}\right\}^{1 / 2}$

enhanced X-ray source with Mo K $\alpha$ radiation $(\lambda=0.71073 \AA){ }^{[22]}$ The selected single crystals were mounted using polybutene oil on a flexible loop fixed on a goniometer head and immediately transferred to the diffractometer. Pre-experiment, data collection, data reduction and analytical absorption correction ${ }^{[23]}$ were performed with the program suite CrysAlisPro. ${ }^{[24]}$ The structures were solved by direct methods using SHELXS97.[25] The structure refinements were performed by full-matrix least- squares on $\mathrm{F}^{2}$ with SHELXL97.[25] PLATON[26] was used to check the result of the X-ray analyses (Table 1). All programs used during the crystal structure determination process are included in the WINGX software. ${ }^{[27]}$ CCDC 958986-958988 contain the supplementary crystallographic data for this paper. ${ }^{[28]} C C D C$-958986: The asymmetric unit of the title compound contains one dicobalt species, nitrate counterions, and isolated solvent molecules of water in a ratio 1/3/1.26. Indeed, one of the three nitrate counter-ions is disordered over two sets of positions with site-occupancy factors of $0.741(3)$ and $0.259(3)$. The available space between these nitrate groups along the $c$ axis is partially occupied by solvent molecules of water [sof $=0.259(3)]$. The $\mathrm{H}$ atoms of the hydroxy groups and of the solvent molecules of water were located in difference Fourier maps and were refined with a soft distance restraint, $\mathrm{O}-\mathrm{H}=0.82(2) \AA$, and with $U_{\text {iso }}(\mathrm{H})=1.5 U_{\text {eq }}(\mathrm{O})$. All other hydrogen positions were calculated after each cycle of refinement using a riding model, with $\mathrm{N}-\mathrm{H}=0.89 \AA$ and $U_{\text {iso }}(\mathrm{H})=1.5 U_{\text {eq }}(\mathrm{N})$. CCDC-958987: The cationic dicobalt molecule has a crystallographically imposed mirror symmetry. The atoms $\mathrm{O} 1, \mathrm{O} 2, \mathrm{C} 1$ and $\mathrm{C} 2$ lie on a mirror plane parallel to the crystallographic $a c$ plane. Two of the three nitrate counter-ions lie also on mirror planes while the third one is disordered over two sets of positions about a mirror plane. The $\mathrm{H}$ atoms of the hydroxy groups and of the solvent molecule of water were located in difference Fourier maps and were refined with a soft distance restraint, $\mathrm{O}-\mathrm{H}$ $=0.82(1) \AA$, and with $U_{\text {iso }}(\mathrm{H})=1.5 U_{\text {eq }}(\mathrm{O})$. All other hydrogen positions were calculated after each cycle of refinement using a riding model, with $\mathrm{N}-\mathrm{H}=0.89 \AA$ and $U_{\text {iso }}(\mathrm{H})=1.5 U_{\text {eq }}(\mathrm{N}) . C C D C-958988$ : The asymmetric unit of the title compound contains one dicobalt species, three nitrate counter-ions, and one isolated solvent molecule of water. The $\mathrm{H}$ atoms of the hydroxy group and of the solvent molecule of water were located in difference Fourier maps and were refined with a soft distance restraint, O-H = 0.82(2) $\AA$, and with $U_{\text {iso }}(\mathrm{H})$ $=1.5 U_{\text {e }}(\mathrm{O})$. All other hydrogen positions were calculated after each cycle of refinement using a riding model, with $\mathrm{N}-\mathrm{H}$ $=0.89 \AA$ and $U_{\text {iso }}(\mathrm{H})=1.5 U_{\text {eq }}(\mathrm{N})$. In all crystal structures, many hydrogen bonds connect all different species together. 


\section{Acknowledgements}

H. B. gratefully acknowledges Prof. emerit. C. Kuenzle, former Vice-Rector for research of the University of Zurich, for his permission to take samples from the Werner Collection and Dr. F. Wild, Institute of Inorganic Chemistry, for taking the photographs of the vials and crystals from the Werner Collection.

Received: January 23, 2014

[1] A. Werner, 'Ueber die Konstitution und Konfiguration von Verbindungen höherer Ordnung', Verlag Julius Springer, Berlin, 1914.

[2] a) A. Werner, 'Neuere Anschauungen auf dem Gebiete der Anorganischen Chemie', Friedrich Vieweg \& Sohn, Braunschweig, Germany, First edition, 1905; b) Second edition, 1909; c) Third edition, 1913; d) Fourth edition, 1920; e) Fifth edition, 1923; f) http://www.scs.illinois. edu/ mainzv/HIST/awards/CCB-2007-Werner. php

[3] H. Berke, Chimia 2009, 63, 541.

[4] a) F. P. Rotzinger, E. Müller, W. Marty, Inorg. Chem. 1987, 26, 3989; b) A. W. Cordes, R. E. Marsh, Acta Cryst. 1968, B24, 283.

[5] P. T. Cleve, Kgl. Sv. Vetensk. Acad. Handl. 1872, 10, No. 9.
[6] S. M. Jörgensen, 'Handbuch der Anorganischen Chemie', 1872, 3, 1106, Gmelin-Kraut.

[7] a) L. Heck, M. Ardon, A. Bino, J. Zapp, J. Am. Chem. Soc. 1988, 110, 2691; b) W. Frank, L. Heck, S. Müller-Becker, T. Raber, Inorg. Chim. Acta 1997, 265, 17.

[8] O. Angern, 'Mehrkernige Kobalt(III)-Ammine', 8th ed., Verlag Chemie GmbH, Berlin, 1930, Vol. 58, pp. 332-368.

[9] A. Werner, Chem. Ber. 1907, 2103.

[10] The University of Zurich possesses a collection of over 2000 original samples originating mainly from the students of Alfred Werner, located at the Institute of Organic Chemistry, University of Zurich, Winterthurer Strasse 190, CH-8057 Zurich.

[11] A. Werner, Annalen, 1910, 375, 1.

[12] A. G. Sykes, R. D. Mast, J. Chem. Soc. (A) 1967, 784.

[13] a) A. Werner, Liebigs Ann. 1910, 375, 1; b) A. Werner, A. Mylius, Z. Anorg. Chem. 1898, 16, 245.

[14] B. Spingler, M. Scanavy-Grigorieff, A. Werner, H. Berke, S. J. Lippard, Inorg. Chem. 2001, 40, 1065.

[15] E. Bindschedler, Inaugural Dissertation, University of Zurich, Zürich, 1901.

[16] E. Welti, Inaugural Dissertation, University of Zurich, Zurich, 1910.
[17] A. Grün, Inaugural Dissertation, University of Zurich, Zurich, 1901.

[18] G. S. Mandel, R.E Marsh, W. P. Schaefer, N. S. Mandel,, B. C. Wang, Acta Cryst. 1977, B33, 3185.

[19] A. Grün, E. Bindschedler, A. Werner, Liebigs Ann. 1910, 121

[20] K. Nakamoto, J. Fujita, H. Murata, J. Am. Chem. Soc. 1958, 80, 4817; W. Hackbusch, H. H. Rupp, K. Wieghardt, J. C. S. Dalton Trans. 1975, 1015.

[21] U. Thewalt, Acta Cryst. B, 1970, 81.

[22] Agilent Technologies (formerly Oxford Diffraction), Yarnton, Oxfordshire, England, 2012

[23] R. C. Clark, J. S. Reid, Acta Cryst. A 1995, 51, 887.

[24] CrysAlisPro, Version 1.171.35.11, Agilent Technologies, Yarnton, Oxfordshire, England, 2012.

[25] G. Sheldrick, Acta Cryst. A 2008, 64, 112.

[26] A. L. Spek, J. Appl. Crystallogr. 2003, 36, 7.

[27] L. Farrugia, J. Appl. Crystallogr. 1999, 32, 837.

[28] Supplementary Material available: CCDC 958986-958988 contain the supplementary crystallographic data for this paper. These data can be obtained free of charge from The Cambridge Crystallographic Data Centre via www.ccdc.cam.ac.uk/data_request/cif. 